\title{
Study on the development the market position company of fully electric vehicles
}

\author{
Wilhelmus Hary Susilo ${ }^{1 *}$ \\ ${ }^{1}$ University of Persada Indonesia Y.A.I, Diponegoro Street 74, Jakarta-10430, Indonesia
}

\begin{abstract}
Owing on decreased the marketing performances on automotive industries- energy generation, and storage industry in many firms. The research inquired of research gap within pursues the market- positions that it was conduct within resources of the corporate. Therefore, the research method conducted the one step approach within the confirmed strategy that conduct within an equation's structural hybrid-model. The results- data was significantly contributed to the goal setting theory that it could drive to improve and enhanced within an innovation evidence in the digitalmarketing and encompassed the marketing strategies that could pursued the market positions within the firms in the automotive fully electric vehicles industry as firms policies that innovation effort in digital marketing more focused than task marketing strategies and top managers.
\end{abstract}

\section{Introduction}

The movement of energy consumptions from fossil- energy to battery- electric vehicle and climate- change and also the disruptive- economics and agile management- era have decreased marketing performances to the development of an automotive industries and energy generation and storage industry that need new strategic- business. Because of situations in sector consumer durable and motor vehicles industries have individual stakeholder $(6.27 \%)$, mutual fund holders $(27.12 \%)$ and other institutional $(19.9 \%)$. Furthermore, The marketing science would drive within an emerging market intended and improve comprises; the competencies, an employee effort, the well task-direction, attempt the persistence and well choice of the strategies, the supposed an experiences in electric vehicles and encouragement the general- managers and the holistic team- work that it was the research gaps that it was could leads to the consumer's value, consumer durable and the marketing-performance $[1,2,3]$.

The market position was conducted within among resources that it has been not to be confirm result on enhance the electric vehicles business [4, 5, 6, 7].

Nevertheless, in pandemic era and almost entire the automotive industries was need the model- agile management to handle, the leadership should has more responsive and, while empirical evidence to the level of difficulty to attempted the market position within collaboration of the marketing relationship on business to business on the complexity industry of motor vehicles in Jakarta $[8,9]$.

* Corresponding author: wilhel16@gmail.com 
Furthermore, the motor vehicles organizational policy-change has alters of the disruptiveeconomics in the recent day within to develop the stakeholders value creation to enhance the market-positions and the performance of the firms- management innovations within the job- experienced of the enterprise's salesperson of fully electric vehicles venture [7, 10-14]. Thus, an inquiry of the recent research should be conduct to fulfilling of research gap on enhance of the market position for the electric- vehicle industries. Further, the focus of an antecedents- to leverage to the market position the fully- electric vehicles enterprise's [2, $11,15-34]$.

In this present study, the sale of fully electric automotive- complexity industry within on marketing divisions entire automotive firms should provide the special business strategic and to improve the market positions on building the digital- relationship with entire consumer in complexity automotive industry $[35,36]$.

Therefore, to enhance of the market- position was drive the new-opportunity to pursue the financial performance and it was build the new ways alters the consumer- value, the improvement of the consumer durables and alignment of the marketing capabilities [37, 38]. In particular, the business plan was choices by the top of managers and it was make improvement of the motor vehicles strategic-business within the high digitalizecompetencies within among employee of fully electric vehicles. Hence, an energy generation within complexity industry pertains; the improvement- vehicles design, digitalize- the modern manufacture, improvement of the automatize-sale and electricity generated [39-52].

Actually, the scholar would make some improvement within the goal setting researchmodel of the market position conducted on the goal setting theory base on the motor vehicles firms to win the competitions within complexity industry, and the management the organization strategies impacted the business- marketing plan for the sustainable and the management practice on the marketing- transformational- digitalized leadership [53-59].

Alignments to investigate the venture of motor vehicles of fully electric vehicles in Jakarta that it would enhance the best- market positions to the disruptive economics and an agile management [60-63].

\subsection{The enhance of market position and the GST}

The researcher was evidence to the goal setting theory as the factors (e.g.; clear-direction, improvement an effort, elevated the persistence and venture-marketing strategy) that it necessary of marketing strategies in the company of fully electric automotive in Jakarta within industries for satisfy to the consumers and enhance the market position $[40,41,59$, $64,65,66]$.

Moreover, the best-market position in the company within entire the salesperson employee and the general top manager of the private-corporate for facing its competitions and disruptive economics situations in the recently of the digitalize era that must be build the digital culture [67-69].

Furthermore, the GST- theory have facing the competition among firm in heterogeneous business in the entire of the automotive firms performance and the sustainable competitive advantage to create the best marketing strategy policy, bundles and provide the toporganization's resources, effect of personalities and perception and for achieving the salesperson experience- performance supported and increased the market position based on the digital marketing- complex task effort [70-84].

The scholars was provide the GST to alignments the research gap of the market position complexity industry and it evolved the body of knowledge within of result the novelty of the research result from an empirical research for pursue the market positions of the firms 
that conducted within the organizational team work and the salesperson within the difficulty- target and an experiment in industry [6, 12, 85-89].

Owing to fulfill the research gap in this study within GST and R-A Theory the research question was how to pursue of the market position within the company of fully electric automotive is positively related in disruptive-economics era.

\subsection{The research-model and necessary hypothesis}

Actually, the enhance of the market position the e-motor vehicles in Jakarta, that it to develop the finding and evolved the management-science to constrain of the superiormarket positions and it conducted by the digitalize-marketing business planning and the international human resources as the expatriate person in complexity industry $[90,91,92$, 93, 94, 95, 96].

After this disruptive economics-business situation within the fully electric vehiclesmarketing firms' performance and enhance of the market position, the study has encompassed of the goal setting difficulty to pursue of the customers durables and the sale of electric vehicles [71, 97].

Further, the management would determine of well mechanism to attempt the market position and digitalize- marketing firms-performance within innovation venture- effort of entire salespersons within the digital marketing and improve the well persistence based and the task marketing strategies of the enterprise's to enhance of the market position $[12,53$, $59,87,98,99]$.

Indeed, the research-model within e-vehicles to pursue the market position within the company of fully electric vehicles as follow Fig. 1, below:

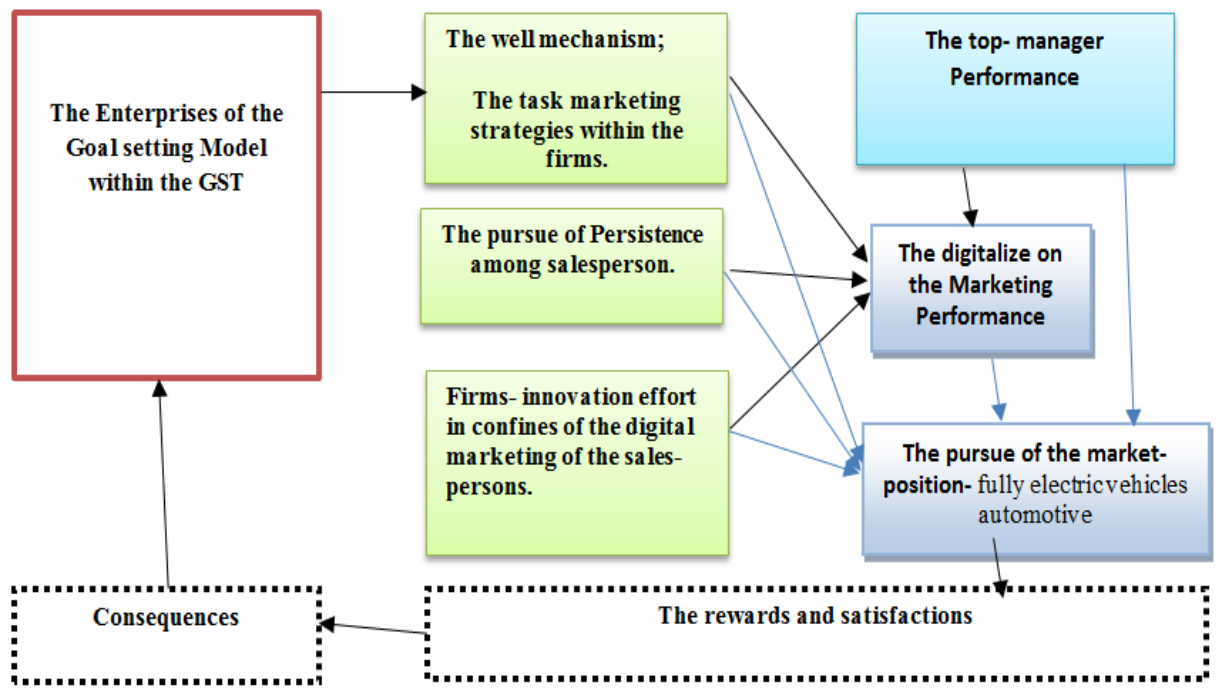

Fig.1. The research-model to pursue on the distinctive market position of the company fully electric vehicles automotive in Jakarta

The hypothesis in this study of the conceptual research model to pursue the market position on the company fully electric automotive in Jakarta, as follow:

$\mathbf{H}_{\mathbf{1}}$ : The pursue of the market position within the company of fully electric automotive is positively related in disruptive- economics era. 


\section{Materials and Methods}

The target populations was conducted within non-probability sampling within the convenience- perception 200 respondents in the company of motor vehicles insustries in Jakarta and JABODETABEK [100-105].

Hence, the quantitative methods and the design of management research conduct with survey and supported by the self-administered questionnaire and it measures the rating scale (1 to 10 rating independently scale) of the latent variables and it responded on enhance the market position in the company of motor vehicles industries [106-108].

Moreover, the test among variables that it conducted within the first CFA test and the goodness of fitted and it conducted within the measurement research- model and the structural equation- modeling phase by the one step approach, in the fully electric vehicles automotive industries [108-112].

Therefore, the latent constructs deployments of the well mechanism evidence to the GSTto pursue of the goal difficulty, challenged and required to enhance the well mechanism that conducted to the effective of the firms- business task marketing to the salesperson target to find out the good ways, enhance the persistence of salespersons and an energizing to innovation effort in the digitalize marketing for achieving the firms-targeted and the role of top manager performance [12, 21, 113].

In particular, to enhance the venture- marketing performance and enhance to the market position-competitive advantage would measure by the very knowledgeable firmssalesperson and improvement an efficient the firms- production process [1, 54, 76, 114,].

\section{Results}

The model should have to conduct by the SEM procedures of an entire the latent were unobserved constructs [103]. Moreover, the measurement of the research-model and the structural has conducted to the confirmatory procedures in the SEM, within the fully automotive industries, the GOFI-model and hypothesis assessment [103, 110,].

Briefly, the empirically- result within motor vehicles industry would have analysis comprise; the sensitivity data (the test not have the outlier and missing data and the $\mathrm{z}$ value $<2.50$ for the bias- data) and the distribution data- multivariate of normality [103].

However, the GOFI- model analyzed within the entire an indexed best-value [108], equally important, in the measurement stage was have the coefficient value to predict within the range of -.10 to 5.08 , the error value was .32 to 2.23 , the contribution value of $\mathrm{R}^{2}$ were .00 to .88 and the significance $t$ value were .16 to 15.88 .

Further, the hypothesis confirmed conducted the coefficient of $t$ value $>2[103,115,116]$, in pandemic situation the researcher would enhance the simulations- data it was determinant on the standard error of means, standard deviation and the amount of the samples and the confident intervals (CI-95\%) and the less- standard error of mean (SEM). In fact, the raw data entire score of observed variables was - .12 to .98 within the covariance matrix [3, 108, 117].

Indeed, the scholars have some analysis within the structural hybrid-model stage to confirmed hyphotesis as indicated in Table 1.

The hybrid model within one- step approach on the company of fully vehicles automotive industry have; the degree of freedom $=120, \mathrm{P}=.00, \mathrm{RMSEA}=.17, \mathrm{NFI}=.62, \mathrm{NNFI}=.56$, $\mathrm{CFI}=.66, \mathrm{IFI}=.66, \mathrm{RFI}=.54, \mathrm{GFI}=.71, \mathrm{AGFI}=.58, \mathrm{PGFI}=.49$, indicted that it was not fit and enought- good hybrid model. An empirival evidance, from table 1, the pursue of the market position (MP) in the company could more determining from the innovation- effort in digital marketing (IEDM) also the firms- task marketing strategies (TMS), and also the persistence of salesperson [54, 88, 97, 98, 118, 119]. 
The yield data within the value of covariance matrix of the among latent variables have the value in the range of .01 (TMP and MP) until 1.61 (IEDM and MP). Moreover, the contribution value of $\mathrm{R}^{2}$ were 1.00 to 1.12 , also the error was on the range .001 to 2.12 . Certainly, the covariance matrix value of the independent variables was on the range of .02 to .72 , event more the covariance matrix of the latent variables was on the range of .02 to $1.61[3,34,52,120-122]$.

The implication to evolve the marketing- management science in this inquiry due to the Top Manager Performance (TMP) $\rightarrow$ Market Position (MP) was confirmed with t value 1.99, therefore the level of TMP could contribute on the body of knowledge within R-A Theory for competitions. Furthermore, owing to an evident based from the result could develop that to evolve marketing science should combine within human resourcesmanagement policy in the firms.

Table 1. The Hyphotesis Confirmed

\begin{tabular}{|c|c|c|c|c|}
\hline The Path-Hyphotesis & Estimate value & Error value & T value & Remarks \\
\hline $\begin{array}{l}\text { Top Manager Performance (TMP) } \\
\rightarrow \text { Digital Marketing Performance } \\
\text { (DMP) }\end{array}$ & .55 & .15 & 3.68 & confirmed \\
\hline $\begin{array}{l}\text { Task Marketing Strategy } \\
\text { (TMS) } \rightarrow \text { Digital Marketing } \\
\text { Performance (DMP) }\end{array}$ & 1.19 & .13 & 9.46 & confirmed \\
\hline $\begin{array}{l}\text { Persistence of Salesperson } \\
\text { (PSP) } \rightarrow \text { Digital Marketing } \\
\text { Performance (DMP) }\end{array}$ & .27 & .036 & 7.56 & confirmed \\
\hline $\begin{array}{l}\text { Innovation Effort Digital } \\
\text { Marketing (IEDM) } \rightarrow \text { Digital } \\
\text { Marketing Performance (DMP) }\end{array}$ & .02 & .047 & .42 & $\begin{array}{l}\text { Not- } \\
\text { confirmed }\end{array}$ \\
\hline $\begin{array}{l}\text { Digital Marketing Performance } \\
\text { (DMP) } \rightarrow \text { Market Position (MP) }\end{array}$ & .29 & .12 & 2.36 & confirmed \\
\hline $\begin{array}{l}\text { Top Manager Performance (TMP) } \\
\rightarrow \text { Market Position (MP) }\end{array}$ & -.66 & .33 & 1.99 & confirmed \\
\hline $\begin{array}{l}\text { Task Marketing Strategy (TMS) } \\
\rightarrow \text { Market Position (MP) }\end{array}$ & 1.50 & .14 & 10.57 & confirmed \\
\hline $\begin{array}{l}\text { Persistence of Salesperson (PSP) } \\
\rightarrow \text { Market Position (MP) }\end{array}$ & .76 & .078 & 9.73 & confirmed \\
\hline $\begin{array}{l}\text { Innovation Effort Digital } \\
\text { Marketing (IEDM) } \rightarrow \text { Market } \\
\text { Position (MP) }\end{array}$ & -1.07 & .089 & 11.94 & confirmed \\
\hline
\end{tabular}

\section{Conclusions}

In summary, the mayor hypothesis; the pursue of the market position within the company of fully electric automotive is positively related in disruptive- economics era that on the hole, was very good to confirmed, that equally important have confirmed the entire 8 hypotheses testing and only hypothesis 4 was not confirmed. In conclusion, (1) Top Manager Performance (TMP) lead to Digital Marketing Performance was significant; (2) Task Marketing Strategy (TMS) lead to Digital Marketing Performance (DMP) was significant; (3) Persistence of Salesperson (PSP) leads to Digital Marketing Performance (DMP); (4) Digital Marketing Performance (DMP) lead to Market Position (MP); (5) Top Manager Performance (TMP) led to Market Position (MP); (6) Task Marketing Strategy (TMS) lead to Market Position (MP); (7) Persistence of Salesperson (PSP) led to Market Position (MP); and (8) Innovation Effort Digital Marketing (IEDM) led to Market Position (MP). 
Moreover, the best firm-value to enhance the market position in among firms - competitive advantage of fully electric vehicles that it conducted by venture- innovation management effort in the digital firms was the best confirmed to enhance the enterprises marketposition. The scholar was alignments to research gap to the new model effectively pursue the marketing performance and to enhance the firms market position- competitive advantage on business (MP).

Hence, the research contributions comprises; first, to the theoretical implications to evolved of marketing science within the motor vehicles industry and the result was conducted with the GST as the firms- predicted to enhance the distinctive- marketing firms performance leveraged the firms-market position. Moreover, the second managerial implication to made some business strategic planning was increased the innovation effort in the digitalize marketing and the best task of marketing strategies of the entire the company of fully electric automotive and the automotive firms could develop the research and development department base on good- performance top manager.

Equally important, for the future study the researcher for made the hybrid model could determine the top manager performance, innovation, task marketing strategy base on digital within the robust data platform, and persistence salesperson to lead market position in advance technologies vehicle.

Finally, the new-novelty was on the Top Manager Performance (TMP) was the most significantly impact to the Digital Marketing Performance (DMP), which is why the resources advantage theory for competitions would confirm besides of the GST.

\section{References}

1. A. Ferdinand, L. Fitriani, Acculturative Iconic Product Attractiveness and Marketing Performance, Journal of Global Strategic Management 2(9),15-15 (2015)

2. P. Matthyssens, R. Bocconcelli, A. Pagano, L. Quintens, Aligning Marketing and Purchasing for new value creation, Industrial Marketing Management 52, 60-73 (2016).

3. W. H. Susilo, The Business Research: The Competency\& Confident- Building Approach (W. H. Susilo Ed. ed.). Lap Lambert Academic Publihing, Riga (2020)

4. P. Harrigan, U. Evers, M. P. Miles, T. Daly, Customer engagement and the relationship between involvement, engagement, self-brand connection and brand usage intent, Journal of Business Research 88, 388-396 (2018)

5. S. Bitter, S. Grabner-Kräuter, Consequences of customer engagement behavior: when negative Facebook posts have positive effects, Electron Markets 26, 13 (2016)

6. J. Y. T., Chang, J. J. Jiang, G. Klein, E. T. G. Wang, Enterprise system programs: Goal setting and cooperation in the integration team, Information \& Management 56(6), 103137 (2019)

7. A. Day, S. N. Crown, M. Ivany, Organisational change and employee burnout: The moderating effects of support and job control, Safety Science 100, 4-12 (2017)

8. M. Sarmento, C., Simões, M. Farhangmehr, Applying a relationship marketing perspective to B2B trade fairs: The role of socialization episodes, Industrial Marketing Management 44, 131-141 (2015)

9. Y. Lindsjørn, D. I. K. Sjøberg, T. Dingsøyr, G. R. Bergersen, T. Dybå, Teamwork quality and project success in software development: A survey of agile development teams, Journal of Systems and Software 122, 274-286 (2016) 
10. P., Sok, A., O’Cass, K. M. Sok, Achieving superior SME performance: Overarching role of marketing, innovation, and learning capabilities, Australasian Marketing Journal (AMJ) 21(3), 161-167 (2013)

11. R. Geraerdts, Customer value creation: A journey in the search of excellence, Industrial Marketing Management 41(1), 11-12 (2012)

12. R. N. Landers, K. N. Bauer, R. C. Callan, Gamification of task performance with leaderboards: A goal setting experiment, Computers in Human Behavior 71, 508-515 (2017)

13. R. M. Stock, Understanding the relationship between frontline employee boreout and customer orientation, Journal of Business Research 69(10), 4259-4268 (2016)

14. H. H. M. Tse, X. Huang, W. Lam, Why does transformational leadership matter for employee turnover? A multi-foci social exchange perspective, The Leadership Quarterly 24(5), 763-776 (2013)

15. H. Demirkan, J. Spohrer, Developing a framework to improve virtual shopping in digital malls with intelligent self-service systems, Journal of Retailing and Consumer Services, 21(5), 860-868 (2014)

16. J., Järvinen, H. Karjaluoto, The use of Web analytics for digital marketing performance measurement, Industrial Marketing Management 50, 117-127 (50)

17. K. Kasper-Brauer, A. Leischnig, Yes, we can! A fuzzy-set analysis of challenges, skills, and enjoyment of work, Journal of Business Research 69(11), 5286-5291 (2016)

18. A. Kianto, J. Sáenz, N. Aramburu, Knowledge-based human resource management practices, intellectual capital and innovation, Journal of Business Research 81, 11-20 (2017)

19. D. Kim, S. T. Cavusgil, E. Cavusgil, Does IT alignment between supply chain partners enhances customer value creation? An empirical investigation, Industrial Marketing Management 42(6), 880-889 (2013)

20. S. M. Landroguez, Developing an integrated vision of customer value, Journal of Services Marketing 27(3), 234-244 (2013)

21. G. Latham, G., Seijts, J. Slocum, The goal setting and goal orientation labyrinth, Organizational Dynamics 45(4), 271-277 (2016)

22. Y.-M. Li, Pricing digital content distribution over heterogeneous channels, Decision Support Systems 50(1), 243-257 (2010)

23. A., Malik, V., Pereira, P. Budhwar, Value creation and capture through human resource management practices, Organizational Dynamics 47(3), 180-188 (2017)

24. J. Matošková, P. Směšná, Human resource management practices stimulating knowledge sharing, Management \& Marketing 12(4), 614-632 (2017)

25. D. Nicole, C. Vaughan, S. Zabihullah, L. Mei, Workplace training and generic and technical skill development in the Australian construction industry, Journal of Management Development 35(4), 486-504 (2016)

26. M. Obal, R. A. Lancioni, Maximizing buyer-supplier relationships in the Digital Era: Concept and research agenda, Industrial Marketing Management 42(6), 851-854 (2013)

27. M. L. Ouakouak, N. Ouedraogo, Antecedents of employee creativity and organisational innovation: an empirical study, International Journal of Innovation Management 21(07), 1750060 (2017) 
28. D. Pittino, F. Visintin, T. Lenger, D. Sternad, Are high performance work practices really necessary in family SMEs? An analysis of the impact on employee retention, Journal of Family Business Strategy 7(2), 75-89 (2016)

29. S. Rakesh, K. Narendra, P. Sandeep, Thought self-leadership strategies and sales performance: Integrating selling skills and adaptive selling behavior as missing links, Journal of Business \& Industrial Marketing 32(5), 652-663 (2017).

30. V. Senichev, Human Resource Diversity and Performance within the Frame of Organizations, Teams and Individuals, Verslas: teorija ir praktika 14(4), 337-345 (2013)

31. D. L. Stone, D. L. Deadrick, K. M. Lukaszewski, R. Johnson, The influence of technology on the future of human resource management, Human Resource Management Review 25(2), 216-231 (2015)

32. B. Walmsley, From arts marketing to audience enrichment: How digital engagement can deepen and democratize artistic exchange with audiences, Poetics 58, 66-78 (2016)

33. M. J. Xerri, S. R. M. Reid, Human resources and innovative behaviour: improving nursing performance, International Journal of Innovation Management 22, 1850019 (2018)

34. W. H. S. Yulius, The Competitive Advantage: Insight from Private Universities, PEOPLE: International Journal of Social Science 4(3), 1240-1252 (2019)

35. K. Mohsen, T.-Y. Eng, The antecedents of cross-functional coordination and their implications for marketing adaptiveness, Journal of Business Research 69(12), 59465955 (2016)

36. W.-L. Wang, E. C. Malthouse, B. Calder, E. Uzunoglu, B2B content marketing for professional services: In-person versus digital contacts, Industrial Marketing Management 81, 160-168 (2019)

37. A. Mitrache, Branding and Marketing - An Architect's Perspective, Procedia - Social and Behavioral Sciences 62, 932-936 (2012)

38. D., Vorhies, N. Morgan, Benchmarking Marketing Capabilities for Sustainable Competitive Advantage, Journal of Marketing 69, 80-94 (2005)

39. H. Guo, H. Xu, C. Tang, Y. Liu-Thompkins, Z. Guo, BDong, Comparing the impact of different marketing capabilities: Empirical evidence from B2B firms in China, Journal of Business Research 93, 79-89 (2018)

40. R. Bravo, J. Matute, J. M. Pina, Corporate identity management in the banking sector: effects on employees' identification, identity attractiveness, and job satisfaction, Service Business 10(4), 687-714 (2015)

41. G. R. Iyer, S. Hong Xiao, A. Sharma, M. Nicholson, Behavioral issues in price setting in business-to-business marketing: A framework for analysis, Industrial Marketing Management 47, 6-16 (2015).

42. E. S. L. Kang, S. Y. Lam, Contingent effects of firm and employee reputations on professional advice adoption, Service Business 11, 345-373 (2017)

43. J. Mullen, E. K. Kelloway, M. Teed, Employer safety obligations, transformational leadership and their interactive effects on employee safety performance, Safety Science 91, 405-412 (2017)

44. J. D. Nahrgang, D. S. DeRue, J. R. Hollenbeck, M. Spitzmuller, D. K. Jundt, D. R. Ilgen, Goal setting in teams: The impact of learning and performance goals on process and performance, Organizational Behavior and Human Decision Processes 122(1), 12 $21(2013)$ 
45. M., Raybould, H. Wilkins, Generic Skills for Hospitality Management: A Comparative Study of Management Expectations and Student Perceptions, Journal of Hospitality and Tourism Management 13(2), 177-188 (2006)

46. M. Sambasivan, M. Abdul, Y. Yusop, Impact of personal qualities and management skills of entrepreneurs on venture performance in Malaysia: Opportunity recognition skills as a mediating factor, Technovation 29(11), 798-805 (2009)

47. R. T. Hamilton, How firms grow and the influence of size and age, International Small Business Journal 30(6), 611-621 (2011)

48. S. Poisson-de Haro, A. Bitektine, Global sustainability pressures and strategic choice: The role of firms' structures and non-market capabilities in selection and implementation of sustainability initiatives, Journal of World Business 50(2), 326-341 (2015)

49. M. Reid, E. Brady, Improving firm performance through NPD: The role of market orientation, NPD orientation and the NPD process, Australasian Marketing Journal 20(4), 235-241 (2012)

50. Z. Wang, P. N. Sharma, J. Cao, From knowledge sharing to firm performance: A predictive model comparison, Journal of Business Research 69(10), 4650-4658 (2016)

51. L. Kachersky, D. Lerman, Bridging marketing's intentions and consumer perceptions, Journal of Consumer Marketing 30(7), 544-552 (2013)

52. W. H. Susilo, The pusuit for brand usage intent: insight in higher education which used the compatible computer, International Review of Management and Marketing 9, 125 132 (2019).

53. S. D. Hunt, Developing successful theories in marketing: insights from resourceadvantage theory, AMS Review 19(1), 15 (2011)

54. G. K. Hunter, N. G. Panagopoulos, Commitment to technological change, sales force intelligence norms, and salesperson key outcomes, Industrial Marketing Management 50, 162-179 (2015)

55. G. P. Latham, Goal setting: a possible theoretical framework for examining the effect of priming goals on organizational behaviour, Current Opinion in Psychology 12, 8588 (2016)

56. D. Corsaro, C. Ramos, S. C. Henneberg, P. Naudé, Actor network pictures and networking activities in business networks: An experimental study, Industrial Marketing Management 40(6), 919-932 (2011)

57. M. M. del Alonso-Almeida, L. Bagur-Femenías, J. Llach, The adoption of quality management practices and their impact on business performance in small service companies: the case of Spanish travel agencies, Service Business 9(1), 57-75 (2013)

58. J. N. Mitchell, D. Bruno, Developing sustainable management theory: goal-setting theory based in virtue, Management Decision 54(2), 304-320 (2016)

59. S. Xu, Y.-C. Wang, H. Wen, A case study for student leadership development: A goal setting perspective, Journal of Hospitality, Leisure, Sport \& Tourism Education 24, 168-177 (2019)

60. S. D. Hunt, Developing successful theories in marketing: insights from resourceadvantage theory, AMS Review 1(2), $72-84$ (2011)

61. S. D. Hunt, The evolution of resource-advantage theory: Six events, six realizations, six contributions, Journal of Historical Research in Marketing 4(1), 7-29 (2012) 
62. I. Estrada, D. Faems, P. de Faria, Coopetition and product innovation performance: The role of internal knowledge sharing mechanisms and formal knowledge protection mechanisms, Industrial Marketing Management 53, 56-65 (2016)

63. B. S. Ivens, C. Pardo, B. Niersbach, A. Leischnig, Firm-internal key account management networks: Framework, case study, avenues for future research, Industrial Marketing Management 58, 102-113 (2016)

64. D. H. Shelby, The evolution of resource-advantage theory: Six events, six realizations, six contributions, Journal of Historical Research in Marketing 4(1), 7-29 (2012)

65. L. Fink, N. Yogev, A. Even, Business intelligence and organizational learning: An empirical investigation of value creation processes, Information \& Management 54, 38-56 (2017)

66. M. Ivanova, S. Ivanov, Affiliation to hotel chains: Hotels' perspective, Tourism Management Perspectives 16, 148-162 (2015)

67. G. T. M. Hult, D. J. Ketchen Jr, T. H. Reus, Organizational learning capacity and internal customer orientation within strategic sourcing units, Journal of Quality Management 6(2), 173-192 (2001)

68. P. Javad Khazaei, K. Masood, K. Ezat Amirbakzadeh, Linking internal marketing orientation to balanced scorecard outcomes in small businesses: the case of travel agencies, International Journal of Culture, Tourism and Hospitality Research 11(3), 297-308 (2017)

69. M. Mitrega, Network partner knowledge and internal relationships influencing customer relationship quality and company performance, Journal of Business \& Industrial Marketing 27(6), 486-496 (2012)

70. T. Bipp, A. Kleingeld, Goal-setting in practice: The effects of personality and perceptions of the goal-setting process on job satisfaction and goal commitment, Personnel Review 40(3), 306-323 (2011)

71. S. D. Hunt, A general theory of business marketing: R-A theory, Alderson, the ISBM framework, and the IMP theoretical structure, Industrial Marketing Management 42(3), 283-293 (2013)

72. D. Alisher Tohirovich, R. Changjoon, Y. Junghyun, Organizational structure and innovation performance: Is employee innovative behavior a missing link? Career Development International 22(4), 334-350 (2017)

73. R. C. Becherer, M. M. Helms, J. P. McDonald, The Effect of Entrepreneurial Marketing on Outcome Goals in SMEs, New England Journal of Entrepreneurship 15(1), 13 (2012)

74. X. Chen, G. P. Latham, The effect of priming learning vs. performance goals on a complex task, Organizational Behavior and Human Decision Processes 125(2), 88-97 (2014)

75. M., Gabrielsson, T., Seppälä, P. Gabrielsson, Realizing a hybrid competitive strategy and achieving superior financial performance while internationalizing in the hightechnology market, Industrial Marketing Management 54, 141-153. (2016)

76. S. D. Hunt, Marketing theory: foundations, controversy, strategy, resource-advantage theory. New York, USA: Routledge Taylor \& Francis Group (2015)

77. S. D. Hunt, R. M. Morgan, The comparative advantage theory of competition, The Journal of Marketing 1-15 (1995) 
78. A. Krausert, HR differentiation between professional and managerial employees: Broadening and integrating theoretical perspectives, Human Resource Management Review 27(3), 442-457 (2017)

79. N. Kumar, A.Yakhlef, Managing business-to-business relationships under conditions of employee attrition: A transparency approach, Industrial Marketing Management 56, 143-155 (2016)

80. K. Nor Shahriza Abdul, R. Mohamed Jalaldeen Mohamed, M. Norshidah, Measuring employee readiness for knowledge management using intention to be involved with KM SECI processes, Business Process Management Journal 18(5), 777-791 (2012)

81. S. Stan De, R. Monique, G. Guy Van, Good employees through good jobs: A latent profile analysis of job types and employee outcomes in the Belgian electricity sector, Employee Relations 39(4), 503-522 (2017)

82. C.-J. Wang, H.-T. Tsai, M.-T. Tsai, Linking transformational leadership and employee creativity in the hospitality industry: The influences of creative role identity, creative self-efficacy, and job complexity, Tourism Management 40, 79-89 (2014)

83. Z. Xiaohong, L. Chengfeng, W. Yanbo, T. Gaowen, The impact of employees' relationships on tacit knowledge sharing, Chinese Management Studies 9(4), 611-625 (2015)

84. G. Zhao, T. Feng, D. Wang, Is more supply chain integration always beneficial to financial performance? Industrial Marketing Management 45, 162-172 (2015)

85. G. Aparicio, R. Basco, T. Iturralde, A. Maseda, An exploratory study of firm goals in the context of family firms: An institutional logics perspective, Journal of Family Business Strategy 8(3), 157-169 (2017)

86. M. Burdina, R. S. Hiller, N. E. Metz, Goal attainability and performance: Evidence from Boston marathon qualifying standards, Journal of Economic Psychology, 58, 7788 (2017)

87. D. Gutt, T. von Rechenberg, D. Kundisch, Goal achievement, subsequent user effort and the moderating role of goal difficulty, Journal of Business Research 106, 277-287 (2020)

88. T. T., Kim, G. Lee, Hospitality employee knowledge-sharing behaviors in the relationship between goal orientations and service innovative behaviour, International Journal of Hospitality Management 34, 324-337 (2013).

89. L. Motel, Increasing diversity through goal-setting in corporate social responsibility reporting. Equality, Diversity and Inclusion: An International Journal 35(5/6), 328-349 (2016)

90. D. Fan, J. Xia, M. M. Zhang, C. J. Zhu, Z. Li, The paths of managing international human resources of emerging market multinationals: Reconciling strategic goal and control means, Human Resource Management Review 26(4), 298-310 (2016)

91. D., Rodwell, A. Hawkins, N. Haworth, G. S. Larue, L. Bates, A. Filtness, A mixedmethods study of driver education informed by the Goals for Driver Education: Do young drivers and educators agree on what was taught? Safety Science 108, 140-148 (2018)

92. F. F. T., Chiang, T. A. Birtch, Pay for performance and work attitudes: The mediating role of employee-organization service value congruence, International Journal of Hospitality Management 29(4), 632-640 (2010) 
93. V. Gupta, S. Singh, A. Bhattacharya, The relationships between leadership, work engagement and employee innovative performance: empirical evidence from the Indian r\&d context, International Journal of Innovation Management 21(07), 1750055 (2017)

94. L. M. Mohamed, Assessing the effects of transformational leadership: A study on Egyptian hotel employees, Journal of Hospitality and Tourism Management 27, 49-59 (2016)

95. R. I. S. Munir, R. A. Rahman, A. M. A. Malik, H. Ma'amor, Relationship between Transformational Leadership and Employees' Job Satisfaction among the Academic Staff, Procedia - Social and Behavioral Sciences 65, 885-890 (2012)

96. R. Silva, O. Gerwe, M. Becerra, Corporate brand and hotel performance: A resourcebased perspective, Journal of Business Research 79, 23-30 (2017)

97. B. Pelin, D. H. Shelby, Alliance market orientation, new product development, and resource advantage theory, Journal of Business \& Industrial Marketing 27(7), 592-600 (2012)

98. C. Deschamps, J. Mattijs, Sustainable goal setting: a large-scale case in management practice, International Journal of Productivity and Performance Management 66(8), 1087-1104 (2017)

99. D. F. L. Santos, L. F. C. Basso, H. Kimura, E. K. Kayo, Innovation efforts and performances of Brazilian firms, Journal of Business Research 67(4), 527-535 (2014)

100.M. Borenstein, L. V. Hedges, J. P. T. Higgins, R. R. Rothstein, Fixed-effect vs Random-effects Introduction to Meta-Analysis, Johnn Willey and Sons (2009)

101.R. Hertwig, T. J. Pleskac, Decisions from experience: why small samples? Cognition 115(2), 225-237 (2010)

102.C. Mathwick, J. Wagner, R. Unni, Computer-Mediated Customization Tendency (CMCT) and the Adaptive e-Service Experience, Journal of Retailing 86(1), 11-21 (2010)

103.W. H. Susilo, The Business Research: The Competency \& Confident- Building Approach (imuruz Ed.). Mauritius: LAMBERT Academic Publishing (2020)

104.E. Thomas, Supplier integration in new product development: Computer mediated communication, knowledge exchange and buyer performance, Industrial Marketing Management 42(6), 890-899 (2013)

105.F. G. S. Vos, H. Schiele, L. Hüttinger, Supplier satisfaction: Explanation and out-ofsample prediction, Journal of Business Research 69(10), 4613-4623 (2016)

106.D. Samson, M. Gloet, P. Singh, Systematic innovation capability: evidence from case studies and a large survey, International Journal of Innovation Management 21(07), 1750058 (2017)

107.A., Stundziene, G., Startiene, R., Remeikiene, M. Dapkus, Does the Survey Data on New Orders Lie? Procedia - Social and Behavioral Sciences 213, 5-11 (2015)

108.W. H. Susilo, Business Research Methods: Market Based Managment Approach in Apllication (S. I. I. Group Ed. First Edition ed.). Bogor, INA: IN MEDIA (2020).

109.L. Agostini, A. Nosella, R. Filippini, Towards an Integrated View of the Ambidextrous Organization: A Second-Order Factor Model, Creativity and Innovation Management 25(1), 129-141 (2016)

110.I. Ghozali, Model Persamaan Structural, Konsep dan Aplikasi Dengan Program AMOS 21.0: Badan Penerbit Universitas Diponegoro (2013).

111.P. Jangl, Model of Market Orientation of High-Tech Firms in Germany: Validation Study, Verslas: teorija ir praktika 17(3), 216-224 (2016) 
112.J. Evermann, M. Tate, Assessing the predictive performance of structural equation model estimators, Journal of Business Research 69(10), 4565-4582 (2016)

113.T. Brashear, P. Bicen, S. D. Hunt, Alliance market orientation, new product development, and resource advantage theory, Journal of Business \& Industrial Marketing 27(7), 592-600 (2012)

114.G. Sugiyarti, A. T. Ferdinand, T. Nurchayati, Acculturative Products Uniqueness Antecedence for Successful Marketing Performance, DLSU Business \& Economics Review 28(1), 11 (2018)

115.L. Deng, M. Yang, K. M. Marcoulides, Structural Equation Modeling With Many Variables: A Systematic Review of Issues and Developments, Frontiers in Psychology 9, 580 (2018)

116.W. H. Susilo, An Impact of Behavioral Segmentation to Increase Consumer Loyalty: Empirical Study in Higher Education of Postgraduate Institutions at Jakarta, Procedia Social and Behavioral Sciences 229, 183-195 (2016)

117.D. S. Akhsanul Khaq, An Increased on Firm Value: Insight in State Owned Enterprises that Listed on the Indonesia Stock Exchange 2013-2018, International Journal of Economic and Financial Issues 10(2), 143-147 (2020)

118.S. Asmus, F. Karl, A. Mohnen, G. Reinhart, The Impact of Goal-setting on Worker Performance - Empirical Evidence from a Real-effort Production Experiment, Procedia CIRP 26, 127-132 (2015)

119.A. Stamatogiannakis, A. Chattopadhyay, D. Chakravarti, Attainment versus maintenance goals: Perceived difficulty and impact on goal choice, Organizational Behavior and Human Decision Processes 149, 17-34 (2018)

120.C. Del Bucchia, C. Lancelot Miltgen, C. A. Russell, C. Burlat, Empowerment as latent vulnerability in techno-mediated consumption journeys, Journal of Business Research 124, 629-651 (2021)

121.I. Ropovik, A cautionary note on testing latent variable models, Frontiers in Psychology 6, 1715 (2015)

122.L. K. Muthén, B. O. Muthén, Mplus Statistical Analysis With Latent Variable User Guide, Muthen \& Muthen (2017). 